\title{
Effects of Bambusae Caulis in liquamen on inhibition of angiotensin-converting enzyme in vitro and blood flow in mouse model
}

\author{
Chun dug Kim ${ }^{1}$, Min Jung Ryu ${ }^{1}$, Hyoung Sik Chun ${ }^{2}$, Geun Pyo Choi ${ }^{3}$, \\ Kwonteak Hwang ${ }^{4 *}$ \\ ${ }^{1}$ Department of Cosmetology science, Nambu University, Gwangju 62271, Korea \\ ${ }^{2}$ Department of Bio-Quality control, Korea Polytechnic Bio Campus, Nonsan 32943, Korea \\ ${ }^{3}$ Department Barista and Bakery, Gangwon State University, Gangneung 25425, Korea \\ ${ }^{4}$ Department of Food and Nutrition, Nambu University, Gwangju 62271, Korea
}

\section{죽력의 in vitro에서의 angiotensin-converting enzyme 저해효과와 마우스모델에서 혈행개선효과}

\author{
김춘득 ${ }^{1} \cdot$ 유민정 $^{1} \cdot$ 전형식 $^{2} \cdot$ 최근표 ${ }^{3} \cdot$ 황권택 $^{4 *}$ \\ ${ }^{1}$ 남부대학교 향장미용학과, ${ }^{2}$ 한국폴리텍대학 바이오품질관리과, \\ ${ }^{3}$ 강원도립대학교 바리스타제과제빵과, ${ }^{4}$ 남부대학교 식품영양학과
}

\begin{abstract}
The purpose of this study was to investigate the effects of the Bambusae Caulis in liquamen (BCL) on blood circulation in animal models. Previous studies on BCL have shown effects on thrombolytic activity and angiotensin-converting enzyme (ACE) inhibitory activity. In the mouse model, the triglyceride content were 301.5 $\mathrm{mg} / \mathrm{dL}$ in the high fat diet+BCL II $0.01 \%$ group, $289.2 \mathrm{mg} / \mathrm{dL}$ in the high fat diet $+\mathrm{BCL}$ II $0.05 \%$ group, which was significantly lower than the high fat diet group. The total cholesterol content was $311.9 \mathrm{mg} / \mathrm{dL}$ in high fat diet+BCL II $0.01 \%$ and $293.7 \mathrm{mg} / \mathrm{dL}$ in high fat diet+BCL II $0.01 \% 0.05 \%$, respectively, which was significantly lower than the high fat diet group. The HDL-cholesterol level was $206.0 \mathrm{mg} / \mathrm{dL}$ for the high fat diet, $196.6 \mathrm{mg} / \mathrm{dL}$ for the high fat diet+BCL II, and $189.2 \mathrm{mg} / \mathrm{dL}$ for the high fat diet+BCL II. There was no significant difference between the $0.01 \%$ and $0.05 \%$ groups. The high-fat diet $+0.05 \%$ group was significantly improved in the blood flow compare to the high fat diet and the high fat diet $+0.01 \%$ group. Platelet aggregation inhibition ability was inhibited in the high fat $\operatorname{diet}+0.01 \%$ and $\mathbf{0 . 0 5 \%}$ groups compared to the high fat diet group.
\end{abstract}

Key words : Bambusae Caulis in liquamen, angiotensin-converting enzyme, blood flow, functional material, lipid improvement

\section{서 론}

우리나라에도 급속한 경제성장과 더불어 생활양식의 서 구화로 인하여 혈중 콜레스테롤 농도 증가로 인한 고혈압,

*Corresponding author. E-mail : hwangskt@nambu.ac.kr Phone : 82-62-970-0174, Fax : 82-62-970-0174

Received 18 September 2017; Revised 21 November 2017; Accepted 23 November 2017.

Copyright (c) The Korean Society of Food Preservation. All rights reserved.
협심증, 급성심근경색증, 관상동맥경화증, 혈전증 등의 혈 액에 관련된 심혈관계 질환 또한 해마다 그 발병률과 사망 률이 증가하고 있는 추세이다(1). 고지혈증은 심혈관 질환 의 대표적 위험요인으로 혈중 LDL-cholesterol 농도는 심혈 관 질환의 이환율과 사망률에 큰 영향을 끼친다(1). 생체 내에서 혈액은 응고와 용해작용이 항상 균형을 이루고 있으 며, 정상적으로 순환되는 동안에는 혈전이 형성되지 않는 다. 그러나 혈액 응고 인자가 지나치게 활성화되거나 혈소 판 응집이 촉진되면 혈류의 항상성이 깨지면서 혈행 이상이 발생되고, 그 결과 혈전증(thrombosis) 및 색전증(embolism) 
이 초래되는 것으로 알려져 있다(2). 혈액 응고 과정에서 과다 생성된 혈전은 혈관 벽에 부착되어 혈류의 흐름을 방해하고, 혈액의 점도를 증가시켜 혈액 순환을 저해하며, 혈액내 산소나 영양소가 조직으로 유입하는 데에도 지장을 초래하게 된다. 혈행 장애에 따른 혈전증 및 색전증은 심근 경색, 뇌졸중 등 심각한 심혈관 질환의 원인이 되며(3), 잘못 된 식습관 및 생활습관, 고지혈증, 고혈압, 당뇨병 등이 혈행 장애를 일으키는 위험요인으로 알려져 있다. 따라서 혈액 의 기능적 이상 및 순환 이상 발생은 다양한 혈관계 질환을 유발하게 되며, 이러한 기능 및 순환 장애가 뇌 및 심장 등에서 나타나는 경우, 생명에 치명적이 되며, 그 후유증 또한 심각하다(4-8).

혈전성 질환을 치료에는 와파린과 같은 항응고제, 아스 피린과 같은 항혈소판제, urokinase나 t-PA와 같은 혈전용 해제를 사용하고 있으며, 혈액의 점도를 낮추기 위해 스타 틴 계열의 콜레스테롤 저하제를 복용하도록 하고 있다. 그 러나 와파린은 출혈의 부작용과 피부 괴사와 같은 부작용이 나타나고(9-11), 아스피린은 위장관 출혈과 같은 부작용이 보고되고 있으며(12), 스타틴 계열의 약제는 혈중 LDL cholesterol 수치를 낮추는 데 효과적이지만 근육관련 질환 부작용이 있다(13). 따라서 근원적으로 심혈관계 질환을 예방할 수 있는 기능성 식품의 개발이 필요하다.

대나무(Bambusoideae)는 외떡잎식물 벼목 벼과에 속하 는 여러해살이 상록 교목의 총칭으로서 중국 중부지역에서 기원된 것으로 알려져 있지만, 온대 및 아열대 지역에 널리 분포되어 있고, 벼과인 Phyllostachys에는 약 75종과 200가 지의 변종이 있는 것으로 알려져 있다 $(14,15)$. 대나무는 예 로부터 오죽, 맹목죽, 참죽, 솜대 등으로 실생활에 유용하게 사용되었으며, 대나무를 이용한 여러 가지 제품들이 그 기 능성에 대한 연구들이 이루어지고 있다. 특히, 죽력은 대나 무를 고온으로 가열하여 채취되는 즙액으로 예로부터 심혈 관계 질환이나 기관지 천식, 중풍, 혈압강하, 해혈작용, 화 상치료, 살균제 등으로 사용되어 왔다(16).

죽력에 대한 연구로는 항산화 기능과 항염증 효과를 가 지고 있는 것으로 알려져 있고(17,18), 세균 및 곰팡이 억제 효과를 가지고 있으며(19), 산화적 스트레스에 대한 신경보 호 효과 $(20,21)$ 가 있는 것으로 보고되었다. 흥분독성과 관 련된 질병의 치료를 위하여 N-methyl-D-aspartate receptor (NMDA)에 의한 신경손상에 대해 대나무 종인 맹종죽( $P$. pubescens), 솜대(P. nigra) 및 왕대(P. bambusoides) 등에서 죽력이 세포사멸 억제효과를 갖는다고 보고하고 있다. 이 와 같이 대나무는 다양한 기능성이 알려져 있으나 깊이 있는 연구, 산업적 수준에서 연구가 충실하지 못한 측면이 있다.

따라서 본 연구에서는 특허(10-0568529)(22)에 기술되어 있는 죽력제조공정으로 생산한 죽력의 효과를 확인하기 위하여 세포수준에서 $\mathrm{ACE}$ 저해효과를 알아보고, 동물모델
에서 혈행개선 효과를 알아보고자 하였다.

\section{재료 및 방법}

\section{실험재료}

담양산 대나무를 사용하여 죽력을 제조하는데 송산제약 에서 설치되어 있는 제조장치를 이용하여 죽력을 제조하였 고 또한 제조된 탄화한 대나무의 경우 대나무 숯으로 제조, 생산된 죽력을 여과하는 재료로 사용하였다. 죽력의 혈행 개선효과를 확인하기 위하여 positive control로 청국장을 사용하였는데 청국장은 노란콩을 5 시간 침지한 다음, 12 $1^{\circ} \mathrm{C}$ 에서 15 분간 증자한 다음, $42^{\circ} \mathrm{C}$ 에서 48 시간 발효하고, 이를 10 배의 물추출을 12 시간 후 filter paper(Whatman No.2)를 이용, 회전증발장치 R-200(BUCHI, Labortechnik, Postfach, Flawil, Switzerland)를 이용, 건조하여 사용하였다.

\section{죽력의 제조공정}

죽력의 생산은 송산제약에서 제작한 간접가열방식의 전 기로를 이용하여 제조하였다. Fig. 1에 도시되어 있는 것처 럼, 로 안으로 출입하는 밀폐형 철제상자에 쪼갠 솜대를 넣고서 밀폐한 후 상자 아랫방향으로 제작된 벨브를 로의 하부에 설치된 죽력 수집장치에 연결시키고 로에서 $350-430^{\circ} \mathrm{C}$ 로 가열하면서 공기의 양을 조절하여 $10-12$ 시간 을 대나무를 철제상사에서 탄화시킨다. 이때 발생하는 연 기를 하부로 연결된 벨브에서 죽력 수집장치로 포집되어

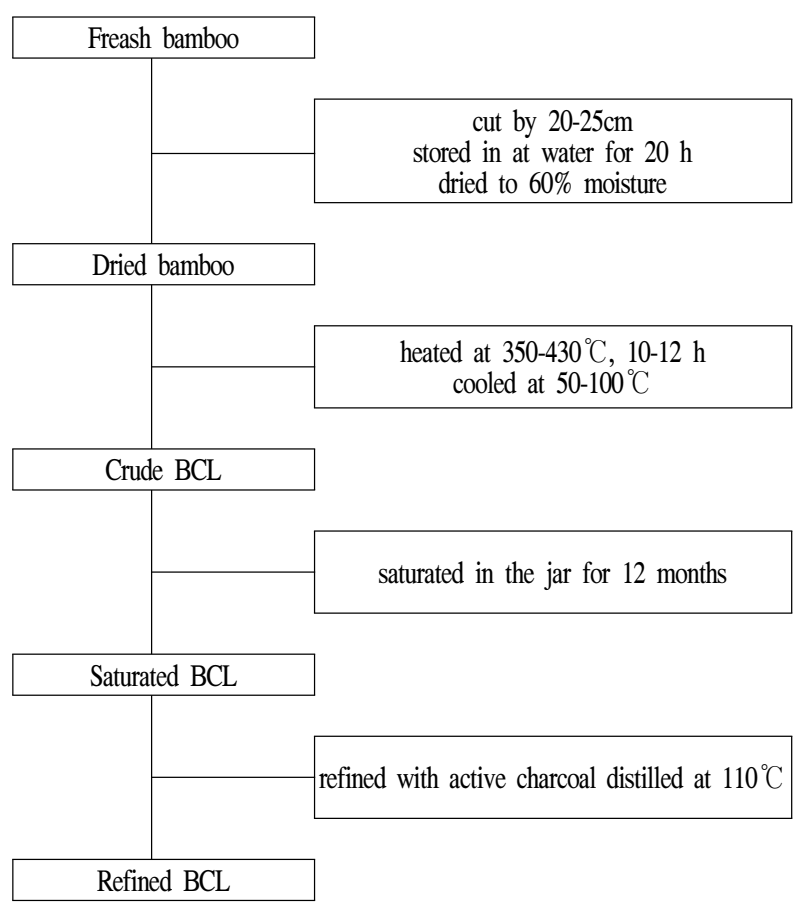

Fig. 1. Manufacturing process of BCL. 
온도가 $80-150^{\circ} \mathrm{C}$ 정도에서 응축시켰으며, 바로 생산된 죽력 시료(bamboo juice)를 6개월 이상 냉소에서 숙성 기간을 거쳐 생산된 시료를 죽력(BCL I)으로 사용하였고, 여기에 탄화과정에서 발생한 대나무 숯을 정제과정의 활성탄으로 사용, 정제 공정으로 하였다. 본 연구에서는 위의 공정에 의해 제조되어 얻은 정제된 정제 시료를 기본으로 하여 취하였다. 정제죽력은 죽력원액에 활성탄(200-250 mesh로 조정) $10 \%(\mathrm{w} / \mathrm{w})$ 혼합 후 $120 \mathrm{rpm}$ 으로 30 분간 저어준 후 12 시간 정치 후 여과한 죽력액 $3 \mathrm{~L}$ 을 $5 \mathrm{~L}$ 증류 flask에 넣은 후 상압증류장치를 이용하여 $108^{\circ} \mathrm{C}$ 로 증류하여 초류분과 후류분을 제거한 증류분을 죽력으로 사용하였으며 증류과 정을 조정 $1.0^{\circ} \mathrm{Brix}$ 로 조정, 이를 원료 죽력(BCLI)으로 사용하였다.

\section{혈전용해능}

죽력원액을 증류수에 $5,000,10,000,15,000,20,000$ ppm 이 되도록 시험용액을 제조하였으며, 혈전용해능 시험은 Astrup과 Mullertz의 방법(23)을 일부 변형하여 수행하였다. 즉, $67 \mathrm{mM}$ sodium phosphate buffer(pH 7.4)에 $0.5 \%$ fibrinogen을 용해시킨 용액 $10 \mathrm{~mL}$ 와 $1 \%$ agarose $10 \mathrm{~mL}$ 를 첨가하여 혼합하고, thrombin(T6884, Sigma-Aldrich, St. Louis, MO, USA)를 50 unit $/ \mathrm{mL}$ 로 $0.2 \mathrm{~mL}$ 를 첨가하여 만든 fibrin plate에 지름 $5 \mathrm{~mm}$ 의 구멍을 만들어 시험용액 20 $\mu \mathrm{L}$ 를 주입하고 $37^{\circ} \mathrm{C}$ 에서 17 시간 반응시켜 이때 생성된 투 명환의 면적을 계산하여 측정하였으며 대조구로는 정제된 혈전용해 효소인 plasmin(1.0 unit $/ \mathrm{mL})$ 을 사용하여 용해 면 적의 상대적인 비율로 환산하였다.

\section{ACE inhibitory activity}

$\mathrm{ACE}$ 활성 저해효과는 Cushman과 Cheung의 방법(24)을 변형하여 측정하였다. ACE enzyme은 rabbit lung acetone powder(Sigma-Aldrich) $1 \mathrm{~g}$ 에 $0.1 \mathrm{M}$ sodium borate buffer(pH 8.3) $40 \mathrm{~mL}$ 를 가하여 $4^{\circ} \mathrm{C}$ 에서 하루 동안 교반한 것을 10,000 $\mathrm{rpm}$ 에서 $4^{\circ} \mathrm{C}, 30$ 분간 원심분리한 후 상등액을 microtube에 $1 \mathrm{~mL}$ 씩 분주하여 $-20^{\circ} \mathrm{C}$ 에 보관하면서 사용하였다. $\mathrm{ACE}$ 측정은 $0.3 \mathrm{M} \mathrm{NaCl}-0.1 \mathrm{M}$ sodium borate buffer(pH 8.3)로 녹인 $12.5 \mathrm{mM}$ HHL(Hip-Hip-Leu, Sigma-Aldrich) 기질 100 $\mu \mathrm{L}$ 에 시료 $10 \mu \mathrm{L}$ 를 첨가하고 sodium borate buffer $45 \mu \mathrm{L}$ 를 가한 후 $37^{\circ} \mathrm{C}$ 에서 5 분간 반응시켰다. 5 분간 반응 후 $\mathrm{ACE}$ enzyme $150 \mu \mathrm{L}$ 를 가하고 다시 $37^{\circ} \mathrm{C}$ 항온수조에서 1 시간 동안 반응시킨 후 $0.5 \mathrm{~N} \mathrm{HCl} 250 \mu \mathrm{L}$ 를 첨가하여 반응을 정지시켰다. 이 반응용액에 ethyl acetate $1.5 \mathrm{~mL}$ 를 넣고 1 분간 혼합한 후 상온에서 $2,800 \mathrm{rpm}, 10$ 분간 원심분리 하여 상등액 $1 \mathrm{~mL}$ 를 취한 후 drying oven에서 $140^{\circ} \mathrm{C}$ 로 20 분간 완전히 열풍건조하고 $1 \mathrm{M} \mathrm{NaCl} 3 \mathrm{~mL}$ 를 가하여 용해시킨 후 $228 \mathrm{~nm}$ 에서 흡광도를 측정하는 통상법과 ACE enzyme 과 sample을 먼저 반응시킨 후 기질을 나중에 첨가하는
방법으로 측정하였다.

$$
\mathrm{ACE} \text { 저해율 }(\%)=\frac{\mathrm{Ec}-\mathrm{Es}}{\mathrm{Ec}-\mathrm{Eb}} \times 100
$$

$\mathrm{Ec}$ : 시료 대신 증류수를 넣었을 때의 흡광도 $\mathrm{Es}$ : 시료 첨가 시의 흡광도

$\mathrm{Eb}$ : 반응 정지 후 시료 첨가한 것을 흡광도

\section{실험동물}

실험동물은 8 주령 $(280 \mathrm{~g})$ 의 Sparague-dawley 계 암컷 흰 쥐를 이용하였고 남부대학교 동물실험윤리위원회의 승인 (승인번호: 201703)을 받은 후 실험을 실시하였다. 실험동 물은 specific pathogen-free 환경에서 사육된 Sprague-dawley 종 암컷 흰쥐 35마리를 (주)오리엔트바이오(Seongnam, Korea)로부터 구입하여 사용하였고, 환경에 적응시키기 위 해 실험 시작 전 1 주일간 예비 사육하였다(25). 대조군 (control group), 고지방 대조군(high fat control group), 고지 방식이와 죽력 $0.01 \%$ 투여군 및 고지방식이와 죽력 $0.05 \%$ 투여군으로 총 4 군으로 나누어 실험 하였다. 예비 사육한 실험동물을 난괴법(randomized complete block design)에 의 해 각 군당 8 마리씩 분배하고 8 주간 사육하였다. 실험동물 사육실의 조건은 온도 $18-24^{\circ} \mathrm{C}$, 습도 $50-60 \%$ 가 유지되도록 하였다. 식이의 구성성분은 AIN-76 식이조성을 기본으로 하고, 고지방 식이는 라아드를 통해 지방 함량을 총 열량의 $40 \%$ 수준으로 증가시켰으며, 고지방 식이에 죽력 $0.01 \%$ 투여군 및 고지방식이와 죽력 $0.05 \%$ 투여했으며, 식이와 물은 자유 급식하였다. 가루 형태로 조제한 식이는 $4{ }^{\circ} \mathrm{C}$ 에 냉장 보관하면서 매일 새로운 식이를 공급하였고, 체중은 일주일에 한번씩 측정하였다. 식이 섭취량은 매일 일정한 시각에 측정하였다.

\section{혈액 채취 및 혈행 성분 분석}

혈액은 실험동물을 해부 전 24시간 절식 시킨 후 ether 마취하에서 개복한 후 대동맥에서 채취하였고, 혈청 중의 지질 농도는 실온에서 한 시간 방치 후 $3,000 \mathrm{rpm}, 4^{\circ} \mathrm{C}$ 에서 10 분간 원심분리하여 분석에 사용하였다. 혈청의 총 지질 (total lipid)의 함량은 혈청 $20 \mu \mathrm{L}$ 에 phosphovanillin 시약을 첨가한 후 $37^{\circ} \mathrm{C}$ 에서 15 분간 배양한 후 시료 무첨가구를 대조로 하여 파장 $540 \mathrm{~nm}$ 에서 흡광도를 측정하였다. 총 콜레스테롤(total cholesterol) 함량은 총 콜레스테롤 측정용 kit시약(AM 202-k, Asan, Hwaseong, Korea)을 사용하였으 며, 중성지방(triglyceride) 함량은 중성지방 측정용 kit시약 (AM 157S-k, Asan), HDL-C(high density lipoprotein cholesterol) 함량의 측정은 HDL-C 측정용 kit시약(AM 203-k, Asan)으로 각각 측정하였으며, 혈중 함량은 표준검 량선에 의해 산출하였다. 


\section{혈류측정}

혈류는 Micro Channel Array Flow Analyzer KH-6 (MC-FAN; MC Laboratory Inc., Tokyo, Japan)을 이용하여 채취한 혈액 $100 \mu \mathrm{L}$ 를 주입하여 측정 하였다.

\section{혈소판 응집력}

Ether 마취 후 개복하여 대동맥으로부터 채혈한 혈액에 $3.2 \%$ sodium citrate용액과 $1: 9$ 의 비율로 혼합한 뒤 1,100 $\mathrm{rpm}$ 에서 10 분간 원심 분리하여 상층의 platelet rich plasma(PRP)를 취하고, $3,000 \mathrm{rpm}$ 에서 10 분간 더 원심분리 하여 상층에 혈장을 제거한 후 EDTA를 포함하는 washed buffer(138 mM NaCl, $2.7 \mathrm{mM} \mathrm{KCl}, 12 \mathrm{mM} \mathrm{NaHCO}_{3}, 0.36$ $\mathrm{mM} \mathrm{NaH} \mathrm{PO}_{4}, 5.5 \mathrm{mM}$ glucose, $1 \mathrm{mM}$ EDTA, pH 6.5) 5 $\mathrm{mL}$ 를 가하고 섞어주어 혈소판을 재현탁시켰다. 이 혈소판 을 다시 $3,000 \mathrm{rpm}$ 에서 10 분간 원심분리 한 후, 세척액을 버리고 혈소판을 위의 방법으로 한번 더 세척하였다. 세척 후 suspending buffer(138 mM NaCl, $2.7 \mathrm{mM} \mathrm{KCl}, 12 \mathrm{mM}$ $\mathrm{NaHCO}_{3}, 0.36 \mathrm{mM} \mathrm{NaH}_{2} \mathrm{PO}_{4}, 5.5 \mathrm{mM}$ glucose, $0.49 \mathrm{mM}$ $\mathrm{MgCl}_{2}, 0.25 \%$ gelatin, $\mathrm{pH}$ 7.4)로 재현탁시켜 3,000 rpm, 10 분간 원심분리한 후 다시 suspending buffer로 현탁시켜 washed platelet을 조제하였다. Washed platelet는 suspending buffer로 희석하여 혈소판 수가 $5 \times 10^{8} / \mathrm{mL}$ 이 되도록 하였고, 응집유도제로 collagen을 $2.5 \mu \mathrm{L}$ 를 가하여 5 분간 반응시켜, Whole blood lumi-aggregometer(Model 560, Chronolog Corporation, Haverton, PA, USA) 를 사용하여 $37^{\circ} \mathrm{C}$ 에서 혈 소판 응집을 측정하였다.

\section{통계학적 분석}

실험결과는 3회 반복하여 평균 \pm 표준오차 $(m e a n \pm S D)$ 로 나타냈으며, SPSS(version 21, IBM Corp., New York, $\mathrm{NY}$, USA) 통계프로그램으로 Student's t-test를 이용하여 $\mathrm{p}<0.05$ 일 때 유의한 것으로 판정하였고, one-way ANOVA 를 실시한 후 $\mathrm{p}<0.05$ 의 유의수준에서 Duncan's multiple range test에 의하여 각 실험군의 평균치 간의 유의성을 검증 하였다.

\section{결과 및 고찰}

\section{혈전용해능 결과}

Fibrin plate상에서 plasmin에 대한 각 시료의 투명환의 상대적 넓이를 비교하여 혈전용해활성을 측정하였다 (Table 1, Fig. 2). 청국장(대조군), 미정제 죽력(BCL I), 정제 죽력(BCL II)그리고 plasmin을 시료로 동일량의 단백질에 대한 활성을 비교한 결과 청국장추출물에서 2.56 unit이였 고, 미정제죽력에서 4.71 unit, 정제죽력에서 4.32 unit를 나 타내어 농도의 차이가 있지만 모두가 plasmin 1.0 unit 보다
유의하게 높은 활성을 보였고, 그 중 미정제 죽력이 가장 높은 활성을 나타내었다. Fig. 2B의 경우 죽력은 간접 탄화 과정을 거치면서 추출되는 용액으로 추출 완료후 이들의 $\mathrm{pH}$ 가 3.0-4.3 에 이르러 혈전용해능이 용액산성화에 의한 효과인지를 확인하고자 $\mathrm{pH}$ 를 $\mathrm{NaOH} 0.1 \mathrm{~N}$ 용액으로 조정하 여 재측정하였더니 원액의 측정결과와 차이점을 발견하지 못하였다. 본 결과에서 미정제 죽력이 가장 우수한 혈전용 해능을 보였으나 미정제 죽력은 식품의약처에 따르면 식품 으로 허가된 주류에 한하여 식품첨가물로 허가되어 있고 일반식품으로는 불허하고 있다. 이는 미정제죽력에서

Table 1. Fibrinolytic activity of extracts from soybean Chungkukjang, BCL I, II, and plasmin

\begin{tabular}{cc}
\hline Sample & $\begin{array}{c}\text { Fibrinolytic activity } \\
\text { (plasmin unit/mL) }\end{array}$ \\
\hline Distilled water & $0.0^{3)(4)}$ \\
Soybean Chungkukjang & $2.56 \pm 0.2^{\mathrm{b}}$ \\
BCL I & $4.71 \pm 0.6^{\mathrm{a}}$ \\
BCL II & $4.32 \pm 0.3^{\mathrm{a}}$ \\
Plasmin & $1.00 \pm 0.2^{\mathrm{a}}$ \\
\hline
\end{tabular}

\footnotetext{
${ }^{1)}$ After 6 months of aging, Non-filterated BCL solution.

${ }^{2)}$ After 6 months of aging, filterated BCL solution.

${ }^{3)}$ After 6 month aging, filterated BCL solution.

${ }^{4 a-b} \mathrm{M}$ Means with different letters in the samples are significnatly different at $\mathrm{p}<0.05$ by Duncan's multiple range test.
}

(A)

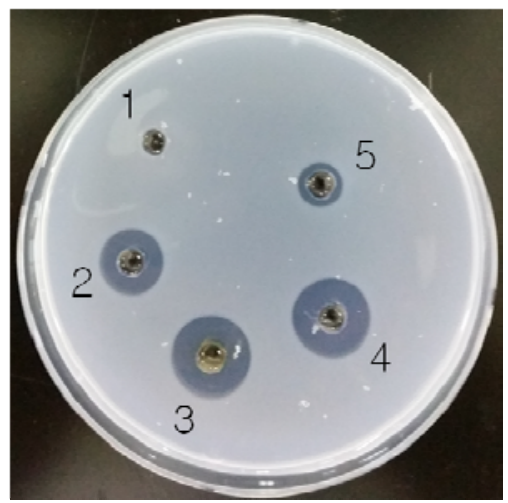

(B)

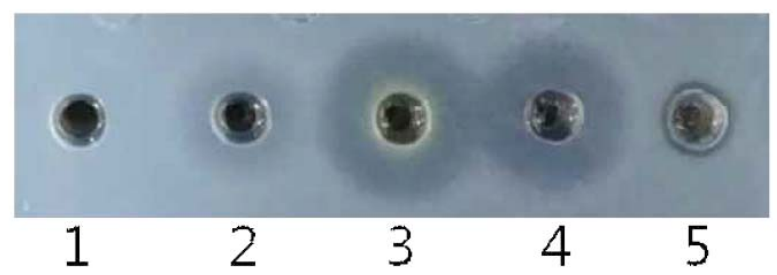

Fig. 2. Fibrinolytic activity of extracts from original samples(A) and (B) original samples of pH-adjusted to 5.0 by $\mathrm{NaOH}$ solution. 1, distilled water; 2, soybean Chungkukjang; 3, BCL I; 4, BCL II; 5, plasmin. 
메탄올, 타르, 벤조피렌 등 일급발암물질이 함유하고 있어 식품으로 허가를 불허하고 있다(26). 본 연구에서는 정제과 정에서 일부성분의 유출로 활성이 떨어지지만 혈전용해 활성이 정제죽력에서도 유지되는 것을 확인하였다.

\section{ACE inhibitory activity}

청국장, 죽력원액(bamboo juice), 미정제 죽력 및 정제죽 력의 $\mathrm{ACE}$ 활성 저해 효과를 확인한 결과는 Table 2에 제시 한 바와 같이 나타났는데 죽력원액, 미정제죽력과 정제죽 력(BCL I, II)에서 각각 $70.25,69.01,68.23 \%$ 의 높은 억제효 과를 보였다. 대조군으로 사용된 청국장에서는 $26.56 \%$ 로 나타나 죽력에서 숙성과정이나 정제과정에서의 차이 없이 통계적으로 유의한 높은 활성을 보이는 것을 확인하였다.

Angiotensin $\Pi$ 는 동맥혈관을 수축하여 혈압을 상승시키 고 부신에서 aldosterone 의 분비를 촉진하여 $\mathrm{Na}$ 및 수분의 재흡수를 촉진시킴으로 고혈압의 원인중 하나로 작용하고 있다(27). 이러한 angiotensin 픈 angiotensinogen이 renin 에 의해 분해된 angiotensin I이 $\mathrm{ACE}$ 에 의해 변환된 것이다 (23). 따라서 특히 청국장, 미정제 죽력을 비교하였을 때 $\mathrm{ACE}$ 활성 저해 효과를 보여 특히 동맥경화증, 혈전증 및 고혈압 예방 등의 혈관 관련성 질환 개선에 도움을 줄 것으로 기대되며, 기능성 식품 및 식재료로 사용하기 위하 여 유효성분 추적 등의 더욱 구체적인 연구가 필요한 것으 로 생각된다.

Table 2. ACE inhibitory activity of extracts from soybean Chungkukjang, bamboo juice, and BCL I and $\Pi$

\begin{tabular}{cc}
\hline Sample & Inhibitory activity $(\%)$ \\
\hline Soybean Chungkukjang & $\left.26.56 \pm 8.6^{4) 65}\right)$ \\
Bamboo juice $^{1)}$ & $70.25 \pm 5.2^{\mathrm{a}}$ \\
BCL I & $69.01 \pm 9.2^{\mathrm{a}}$ \\
BCL II & $68.23 \pm 0.2^{\mathrm{ab}}$ \\
\hline
\end{tabular}

\footnotetext{
${ }^{1)}$ Non-filterated $\mathrm{BCL}$ solution.

${ }^{2)}$ After 6 months of aging, non-filterated BCL solution.

${ }^{3)}$ After 6 months of aging, filterated BCL solution.

${ }^{4)}$ Each value represents mean \pm SD $(n=3)$.

${ }^{5}$ Means with different letters in the samples are significnatly different at $p<0.05$ by Duncan's multiple range test.
}

\section{혈청 중 지질 조성의 변화}

혈행개선과 관련한 세포수준에서 가능성을 확인하고 동 물수준에서 혈행개선 효과를 확인하고자 동물실험을 실시 하였다. Table 3 는 고지방식이를 한 흰쥐에 정제죽력의 함 량을 달리한 식이의 조정을 표시하였고, Table 4에서는 정 제죽력의 함량을 달리하여 동물에 투여 후 혈청 중 triglyceride와 total-cholesterol 및 HDL-cholesterol의 농도 변화를 나타내었다. 8주간의 죽력정제물의 투여를 달리한 동물실험에서 투여 후 실험동물의 몸무게 변화나 먹이섭취
율이 모든 그룹에서 차이가 나타나지는 않았다(data not shown). 고지방식이군은 일반식이군 $(271.1 \mathrm{mg} / \mathrm{dL})$ 에 비해 triglyceride의 함량은 $314.4 \mathrm{mg} / \mathrm{dL}$ 로 증가하였고, 고지방식 이+죽력 $0.01 \%$ 군은 $301.5 \mathrm{mg} / \mathrm{dL}$ 로 나타났으며, 고지방식 이+죽력 $0.05 \%$ 군은 $289.2 \mathrm{mg} / \mathrm{dL}$ 로 유의하게 중성지질이 감소되었다.

또한, 고지방식이군은 일반식이군 $(283.2 \mathrm{mg} / \mathrm{dL})$ 에 비해 total-cholesterol 함량은 $327.2 \mathrm{mg} / \mathrm{dL}$ 로 증가하였으며, 고지 방식이+죽력 $0.01 \%$ 군은 $311.9 \mathrm{mg} / \mathrm{dL}$ 로 나타났으며, 고지 방식이+죽력 $0.05 \%$ 군은 $293.7 \mathrm{mg} / \mathrm{dL}$ 으로 유의하게 totalcholesterol이 감소되는 경향을 보였다. HDL-cholesterol은 일 반식이군이 $206.0 \mathrm{mg} / \mathrm{dL}$ 로 가장 높은 값을 나타내었으며, 고지방식이+죽력 $0.01 \%$ 군 $196.6 \mathrm{mg} / \mathrm{dL}$, 고지방식이+죽력 $0.05 \%$ 군 $189.2 \mathrm{mg} / \mathrm{dL}$, 고지방식이군 $162.2 \mathrm{mg} / \mathrm{dL}$ 순으로 나타났고, 죽력첨가군 $0.01 \%$ 군과 $0.05 \%$ 군 간의 유의성은 없었다.

\section{혈류개선효과}

혈행 개선에는 혈액을 구성하는 혈장 및 혈구세포(혈소 판) 가 주로 관여하며, 이들은 혈류의 항상성을 유지시키며 혈관의 손상된 부위나 염증 부위에서 정상적인 지혈과 보호 작용을 유지함으로써 인체의 정상적인 기능을 유지한다 $(14,15)$.

혈류의 흐름에 미치는 죽력의 영향을 검토해보기 위해 정상식이군, 고지방식이군과 고지방식이+죽력 $0.01 \%$ 군, 고지방식이+죽력 $0.05 \%$ 군의 혈액을 각각 채취하여 헤파린 처리 후, 시각적이고 정량적으로 혈액의 유동성을 인식하 여 혈액의 속도를 측정할 수 있는 micro channel array flow analyzer(MCFAN)를 이용하여 일정한 압력으로 혈액이 모 세관을 $25,50,75,100 \mu \mathrm{L}$ 통과하는 시간을 측정하였다 (Table 5). 실험결과 정상식이군이 고지방식이군에 비해 빠 른 시간에 모세관을 통과하였다. 또한 고지방식이+죽력 $0.05 \%$ 군이 고지방식이군과 고지방식이+죽력 $0.01 \%$ 군보 다 모두 유의하게 빠르게 모세관을 통과하여 빠른 혈액 유동성을 나타내었다. 이상의 결과에서 고지방식이로 인한 지질대사의 영향으로 혈류의 모세혈관 통과속도가 다소 늦어졌으나 일정량의 죽력 추출물 투여에 의해 혈류의 속도 가 빨라짐을 볼 수 있어 혈류흐름을 개선하는 것을 볼 수 있었다. 이러한 대나무 추출물인 죽력에서 주요물질에 대 한 연구는 대나무에서 유도되어진 lignocresol이 caspase-3 활동의 억제된 신경암세포에서 과산화수소에 대항하여 세 포사멸 억제효과를 보였다고 소개하고 있으며, 죽력 성분 중 2-methxoy-p-cresol이 그와 같은 효과를 보이는 것으로 생각되어지며, 이는 lignophenol이 높은 페놀성 기능을 나타 내며 in vitro 상에서 항산화 효과를 나타내는 p-cresol 유도 체이기 때문이라는 조사가 있었다(28). 
Table 3. Ingredient of diet

\begin{tabular}{|c|c|c|c|c|}
\hline \multirow{2}{*}{ Ingredient } & \multicolumn{4}{|c|}{ Diet $(\%, \mathrm{w} / \mathrm{w})$} \\
\hline & Normal diet & High-fat diet & High-fat diet+BCL ${ }^{1)} 0.01 \%$ & High-fat diet+BCL $0.05 \%$ \\
\hline Casein & 14.0 & 14.0 & 14.0 & 14.0 \\
\hline L-cystein & 0.18 & 0.18 & 0.18 & 0.18 \\
\hline Corn starch & 46.0 & 34.0 & 34.0 & 34.0 \\
\hline Dextrinized corn starch & 15.5 & 15.5 & 15.5 & 15.5 \\
\hline Sucrose & 10.0 & 10.0 & 10.0 & 10.0 \\
\hline Fiber & 5.0 & 5.0 & 5.0 & 5.0 \\
\hline Soybean oil & 4.0 & 4.0 & 4.0 & 4.0 \\
\hline AIN-93 mineral Mix. & 3.5 & 3.5 & 3.5 & 3.5 \\
\hline AIN-93 vitamin Mix. & 1.0 & 1.0 & 1.0 & 1.0 \\
\hline Cholin bitartrate & 0.25 & 0.25 & 0.25 & 0.25 \\
\hline TBHQ (mg) & 0.8 & 0.8 & 0.8 & 0.8 \\
\hline Lard & & 12.0 & 12.0 & 12.0 \\
\hline BCL $\square$ & & & 0.01 & 0.05 \\
\hline Total & 100.23 & 100.23 & 100.24 & 100.28 \\
\hline
\end{tabular}

${ }^{1)}$ After 6 months of aging, filterated BCL solution.

Table 4. Effects of extracts of BCL on serum triglyceride, total cholesterol and HDL-cholesterol concentrations in rat fed with high-fat diet for 8 weeks

\begin{tabular}{ccccc} 
& & & $(\mathrm{mg} / \mathrm{dL})$ \\
\hline & Normal diet & High-fat diet & High-fat diet+BCL & High-fat diet+BCL $0.01 \%$ \\
\hline Triglyceride & $271.1 \pm 6.0^{\mathrm{c} 2}$ & $314.4 \pm 8.2^{\mathrm{a}}$ & $301.5 \pm 3.4^{\mathrm{b}}$ & $289.2 \pm 8.0^{\mathrm{bc}}$ \\
Total-cholesterol & $283.2 \pm 3.6^{\mathrm{c}}$ & $327.2 \pm 4.5^{\mathrm{a}}$ & $311.9 \pm 5.8^{\mathrm{b}}$ & $293.7 \pm 4.8^{\mathrm{bc}}$ \\
HDL-cholesterol & $206.0 \pm 8.4^{\mathrm{a}}$ & $162.2 \pm 3.1^{\mathrm{c}}$ & $196.6 \pm 9.1^{\mathrm{b}}$ & $189.2 \pm 7.5^{\mathrm{b}}$ \\
\hline
\end{tabular}

${ }^{1)}$ After 6 months of aging, filterated BCL solution.

${ }^{2) a-c}$ Means $(n=8)$ with different letters in the samples are significnatly different at $p<0.05$ by Duncan's multiple range test.

Table 5. Effect of extracts of BCL on micro channel array flow

\begin{tabular}{ccccc}
\hline \multirow{2}{*}{ Group } & \multicolumn{4}{c}{ Flow time (min) } \\
\cline { 2 - 5 } & $25 \mu \mathrm{L}$ & $50 \mu \mathrm{L}$ & $75 \mu \mathrm{L}$ & $100 \mu \mathrm{L}$ \\
\hline Normal diet & $10.06 \pm 1.31^{\mathrm{a} 2)}$ & $21.35 \pm 2.60^{\mathrm{a}}$ & $37.39 \pm 3.75^{\mathrm{a}}$ & $52.29 \pm 4.25^{\mathrm{a}}$ \\
High-fat diet & $14.36 \pm 0.58^{\mathrm{c}}$ & $27.43 \pm 1.39^{\mathrm{c}}$ & $46.05 \pm 8.93^{\mathrm{c}}$ & $71.06 \pm 13.06^{\mathrm{c}}$ \\
$\begin{array}{c}\text { High-fat diet+BCL } \\
0.01 \%\end{array}$ & $11.63 \pm 1.13^{\mathrm{b}}$ & $26.87 \pm 5.02^{\mathrm{b}}$ & $42.15 \pm 2.73^{\mathrm{b}}$ & $59.12 \pm 2.81^{\mathrm{b}}$ \\
$\begin{array}{c}\text { High-fat diet+BCL } \\
0.05 \%\end{array}$ & $10.03 \pm 0.71^{\mathrm{c}}$ & $21.73 \pm 1.592^{\mathrm{c}}$ & $35.45 \pm 2.94^{\mathrm{c}}$ & $53.12 \pm 5.03^{\mathrm{c}}$ \\
\hline
\end{tabular}

\footnotetext{
${ }^{1)}$ After 6 months of aging, filterated BCL solution.

${ }^{2) a-c}$ Means $(n=8)$ with different superscript letters in the same column are significnatly different at $p<0.05$ by Duncan's multiple range test.
}

\section{혈소판 응집에 미치는 영향}

죽력의 혈소판 응집 억제 효과를 검토해보기 위하여 washed platelet을 분리하고 collagen $2 \mu \mathrm{g}$ 으로 혈소판 응집 을 유도하였다. 죽력 추출물의 항혈소판 응집에 미치는 영
향을 검토한 결과(Table 6), 고지방식이군의 경우 대조군인 일반식이군에 비해 혈소판 응집이 증가한 반면 고지방식이 +죽력 $0.01 \%$ 군과 고지방식이+죽력 $0.05 \%$ 군은 고지방식이 군에 비해 혈소판응집이 억제되는 것으로 나타났다. Amplitude(\%)는 혈소판 응집율을 나타낸 것으로 수치가 작을수록 시료의 항혈소판 응집효과가 큰 것을 의미한다. Amplitude(\%)의 경우, 고지방식이군은 일반식이군과 비교 하였을 때 121.27로 증가하였으나 고지방식이+죽력 $0.01 \%$ 군, 고지방식이+죽력 $0.05 \%$ 군은 응집율이 각각 $102.44 \%$ 와 $101.26 \%$ 로 유의하게 감소하는 경향이 나타났다.

$\operatorname{Slop}(\Omega / \mathrm{min})$ 은 혈소판 응집에 대한 기울기로 ohm 수치가 클수록 collagen 응집제로 인해 혈소판의 응집이 급격하게 이루어진 것을 의미하는데 고지방식이군은 일반식이군 (139.40 $\Omega / \mathrm{min})$ 과 비교하였을 때 $151.38 \Omega / \mathrm{min}$ 으로 증가하 였으나 고지방식이+죽력 $0.01 \%$ 군, 고지방식이+죽력 $0.05 \%$ 군에서 역시 $149.46 \Omega / \mathrm{min}$ 와 $140.14 \Omega / \mathrm{min}$ 으로 유의하게 
감소하는 경향이 나타났다. Lag time(sec)은 혈소판 응집이 일어나는 반응시간으로 반응시간이 짧을수록 collagen 응 집제로 인해 혈소판의 응집이 급격하게 이루어진 것을 의미 한다. 고지방식이군은 일반식이군 $(36.56 \mathrm{sec})$ 과 비교하여 $24.27 \mathrm{sec}$ 로 감소한 것에 반해 고지방식이+죽력 $0.01 \%$ 군, 고지방식이+죽력 $0.05 \%$ 군은 고지방식이군에 비하여 응집 시간이 $28.62 \mathrm{sec}$ 와 $30.12 \mathrm{sec}$ 로 증가하여 응집이 지연되는 결과를 나타내었다.

Table 6. Effect of extracts of BCL against collagen induced platelet aggregation

\begin{tabular}{cccc}
\hline Group & Amplitude (\%) & Slope $(\Omega / \mathrm{min})$ & Lag time (sec) \\
\hline Normal diet & $108.51 \pm 2.03^{\mathrm{b} 2)}$ & $139.40 \pm 8.53^{\mathrm{bc}}$ & $36.56 \pm 10.08^{\mathrm{a}}$ \\
High-fat diet & $121.27 \pm 4.05^{\mathrm{a}}$ & $151.38 \pm 2.15^{\mathrm{a}}$ & $24.27 \pm 2.52^{\mathrm{bc}}$ \\
High-fat diet+BCL 0.01\% & $102.44 \pm 3.29^{\mathrm{c}}$ & $149.46 \pm 4.38^{\mathrm{ab}}$ & $28.62 \pm 4.70^{\mathrm{ab}}$ \\
High-fat diet+BCL 0.05\% & $101.26 \pm 3.47^{\mathrm{c}}$ & $140.14 \pm 6.51^{\mathrm{b}}$ & $30.12 \pm 10.81^{\mathrm{ab}}$ \\
\hline
\end{tabular}

${ }^{1)}$ After 6 months of aging, filterated BCL solution.

${ }^{2) a-c}$ Means $(n=8)$ with different superscript letters in the same column are significnatly different at $\mathrm{p}<0.05$ by Duncan's multiple range test.

\section{요 약}

대나무 죽력의 $\mathrm{ACE}$ 저해효과와 마우스모델에서의 혈행 개선 효과를 보았다. 혈전용해능에서 청국장추출물은 2.56 unit, 미정제죽력에서 4.71 unit, 정제죽력에서 4.32 unit를 나타내어 모두가 plasmin 보다 유의하게 높은 활성이 높고, $\mathrm{ACE}$ 활성 저해 효과에서는 죽력 원액, 미정제 죽력과 정제 죽력에서 각각 $70.25 \%, 69.01 \%, 68.23 \%$ 로 대조군으로 사용 된 청국장이 $26.56 \%$ 으로 나타나 높은 억제효과를 보였다. 마우스모델시험에서 고지방식이군과 함께 고지방식이군+ 정제죽력 $0.01 \%$ 와 $0.05 \%$ 를 투여, 혈청 중 지질변화에서 triglyceride의 함량은 고지방식이군이 일반식이군(271.1 $\mathrm{mg} / \mathrm{dL}$ )에 비해 $314.4 \mathrm{mg} / \mathrm{dL}$ 로 증가하였고, 고지방식이+죽 력 $0.01 \%$ 군은 $301.5 \mathrm{mg} / \mathrm{dL}$ 로 나타났으며, 고지방식이+죽 력 $0.05 \%$ 군은 $289.2 \mathrm{mg} / \mathrm{dL}$ 으로 유의하게 중성지질이 감소 를 나타내었고, total-cholesterol 함량은 $327.2 \mathrm{mg} / \mathrm{dL}$ 로 증가 하였으며, 고지방식이+죽력 $0.01 \%$ 군은 $311.9 \mathrm{mg} / \mathrm{dL}$ 로 나 타났으며, 고지방식이+죽력 $0.05 \%$ 군은 $293.7 \mathrm{mg} / \mathrm{dL}$ 로 고 지방식이군에 비교, 유의하게 total-cholesterol이 감소세를 나타내었다. 한편 HDL-cholesterol은 일반식이군이 206.0 $\mathrm{mg} / \mathrm{dL}$ 로 가장 높은 값을 나타내었으며, 고지방식이+죽력 $0.01 \%$ 군 $196.6 \mathrm{mg} / \mathrm{dL}$, 고지방식이+죽력 $0.05 \%$ 군 189.2 $\mathrm{mg} / \mathrm{dL}$, 고지방식이군 $162.2 \mathrm{mg} / \mathrm{dL}$ 순으로 나타났고, 죽력첨 가군 $0.01 \%$ 군과 $0.05 \%$ 군간의 유의성은 없었다. 혈류개선 효과에서는 고지방식이에 비하여 고지방식이+죽력 $0.05 \%$ 군이 고지방식이군, 고지방식이+죽력 $0.01 \%$ 군보다 모두
유의하게 빠르게 모세관을 통과하여 빠른 혈액 유동성을 나타내었다. 혈소판응집 억제능에서는 고지방식이군의 경 우 대조군인 일반식이군에 비해 혈소판 응집이 증가한 반면 고지방식이+죽력 $0.01 \%$ 군과 고지방식이+죽력 $0.05 \%$ 군은 고지방식이군에 비해 혈소판응집이 억제되는 것으로 나타 났다.

\section{감사의 글}

본 연구는 산업통상자원부와 한국산업기술진흥원의 “지 역특화산업육성사업”으로 수행된 연구결과이며 이에 감사 를 드립니다(과제번호 R0004129).

\section{References}

1. National Cholesterol Education Program (NCEP) (2002) Third report of the national cholesterol education program (NCEP) expert panel on detection, evaluation, and treatment of high blood cholesterol in adults (adult treatment panel III) final report. Circulation. 106, 3143-3421

2. Shim YY, An JH, Cho WD, Chun H, Kim KI, Cho HY, Yang HC (2002) Inhibitory Mechanism of Blood Coagulation and in vivo Anticoagulant Activities of Polysaccharides Isolated from Codium fragile. J Korean Soc Food Sci Nutr, 31, 917-923

3. Noh KH, Park CM, Jang JH, Shin JH, Cho MK, Kim JO, Song YS (2009) Effects of nattokinase fibrinol supplementation on fibrinolysis and atherogenesis. J Life Sci, 19, 289-298

4. Park, DK, Park HJ (1990) Studies on the effect of rat platelet aggregation by ginkgo and perilla oil dietary. J Korean Soc Food Nutr, 19, 127-132

5. Park SH, Park KJ, Kim JK (2009) The effects of mume fructus extracts on blood flow improvement. Yakhak Hoeji, 53, 298-302

6. Klafke JZ, Arnoldi da Silva M, Fortes Rossato M, Trevisan G, Bandero Walker CI, Martins Leal CA, Olschowsky Borges D, Chitolina Schetinger MR, Noal Moresco R, Medeiros Frescura Duarte MM, Soares Dos Santos AR, Nazario Viecili PR, Ferreira J (2012) Antiplatelet, antithrombotic, and fibrinolytic activities of Campomanesia xanthocarpa. Evidence-Based Complementary Altern Med, 2012, 1-8

7. Davies MJ, Thomas AC (1985) Plaque fissuring-the cause 
of acute myocardial infarction, sudden ischaemic death, and crescendo angina. Br Heart J, 53, 363-373

8. Lau AJ, Toh DF, Chua TK, Pang YK, Woo SO, Koh HL (2009) Antiplatelet and anticoagulant effects of Panax notoginseng: Comparison of raw and steamed Panax notoginseng with Panax ginseng and Panax quinquefolium. J Ethnopharmacol, 125, 380-386

9. May AE, Seizer P, Gawaz M (2008) Platelets: inflammatory firebugs of vascular walls. Arterioscler Thromb Vasc Biol, 28, 5-10

10. Ahn SH, Choo IS, Kim DM, Lim GH, Kim JH, Kim HW (2008) Warfarin induced skin necrosis. J Korean Neurol Assoc, 26, 142-145

11. Bircher AJ, Harr T, Hohenstein L, Tsakiris DA (2006) Hypersensitivity reactions to anticoagulant drugs: diagnosis and management options. Allergy, 61, 1432-1440

12. Wong KS, Mok V, Lam WW, Kay R, Tang A, Chan YL, Woo J (2000) Aspirin associated intracerebral hemorrhage: clinical and radiologic features. Neurology, 54, 2298-2301

13. Kim YH, Kim KW, Ahn SH, Oh MS, Ma HI, Kim YJ, Lee BC (2014) Myotonic potentials in the myopathy induced by HMG-CoA reductase inhibitor. J Korean Neurol Assoc, 32, 186-189

14. Jang KS, Choi CH, Jung DJ (2001) Effects of balbusae caulis in liquamen extracted from bamboo charcoal manufacturing process on the blood sugar of the mice induced with streptozotocin (II). Korean J Orient Med Physiol Pathol, 15, 469-472

15. Kook K, Kim KH (2003) The effects of supplemental levels of bamboo vingar on growth performance, serum profile and meat quality in fattening Hanwoo cow. J Anim Sci Technol, 45, 57-68

16. Jang IK, Hong ND (1985) Experimental studies on the acute toxicity and the efficacy of Phyllostachys juciice. The Kor Soc For Oriental Internal Medicine, 2, 83-201

17. Kang JA, Kang JS (1997) Effect of garlic an onion plasma an liver cholesterol and triglyceride and plate aggregation in rat basal or cholesterol supplemented diets. Korean J Nutr, 32, 132-138

18. Shin KS., Lee JJ, Jin YR, Yu JY, Park ES, Im JH,
You SH, Oh KW, Lee MK, Wee JJ, Kim YS, Yun YP (2007) Effect of korean red ginseng extract on blood circulation in healthy volunteers: A randomized, double-blind, placebo-controlled traial. J Ginseng Res, 31, 109-116

19. Cushman DW, Cheung HS (1971) Spectrophotometric assay and properties of the angiotensin-converting enzyme of rabbit lung. Biochem Pharmacol, 20, $1637-1648$

20. Chun H, Zhang Y, David DK (2000) Evaluation of antioxidant and prooxidant activities of bamboo Phyllostachys nigra Var. Henonis Leaf Extract in vitro. J Agric Food Chem, 48, 3170-3176

21. Yang JH, Choi MH, Yang SH, Cho SS, Park SJ, Shin $\mathrm{HJ}$, Ki SH (2017) Potent anti-inflammatory and antiadipogenic properties of bamboo (Sasa coreana Nakai) leaves extract and its major constituent flavonoids. J Agric Food Chem, 65, 6665-6673

22. Moon JS, Chang KS (2006) Extraction Device for Extracting Oil from Bamboo. Patent 10-0568529

23. Astrup T, Mullertz S (1952) The fibrin plate method for estimating fibrinolytic activity. Arch Biochem Biophys, 40, 346-351

24. Cushman DW, Cheung HS, Sabo EF, Ondetti MA (1977) Design of potent competitive inhibitors of angiotensinconverting enzyme. Carboxyalkanoyl and mercaptoalkanoyl amino acids. Biochem, 16, 5484-5491

25. Park JH, Kim JM, Park EJ, Lee KH (2008) Effect of Chungkukjang added with onion on lipid and antioxidant metabolisms in rats fed high fat cholesterol diet. J Korean Soc Food Sci Nutr, 37, 1244-1250

26. KFDA (2011) Some revision of standards and specifications of food KFDA Notice No. 2011-46, 19

27. Cushman DW, Cheung HS (1971) Spectrophotometric assay and properties of the angiotensin-converting enzyme of rabbit lung. Biochem Pharmacol, 20, 1637-1648

28. Kang HY, Lee HJ, Cho HJ, Park DK, Choi IG, Jung YB, Hong YJ, Na KJ (2010) Protective Agent of Bambusae Caulis in Liquamen on the Against Neuronal Damage and Hematoaggregation and There of Composition. Patent No. 10-2009-0106284 